\title{
Molecular identification and histopathological study of natural Streptococcus agalactiae infection in hybrid tilapia (Oreochromis niloticus)
}

\author{
AA Laith ${ }^{1,2}$, Mohd Azmi Ambak ${ }^{1,2}$, Marina Hassan ${ }^{1,2}$, Shahreza Md. Sheriffi, ${ }^{1,2}$ Musa Nadirah ${ }^{1,2}$, \\ Ahmad Shuhaimi Draman², Wahidah Wahab², Wan Nurhafizah Wan Ibrahim¹, Alia Syafiqah Aznan ${ }^{1}$, \\ Amina Jabar ${ }^{3}$ and Musa Najiah ${ }^{1,2}$
}

\begin{abstract}
1. School of Fisheries and Aquaculture Sciences, Universiti Malaysia Terengganu, 21030 Kuala Terengganu, Malaysia; 2. Institute of Tropical Aquaculture (AQUATROP), Universiti Malaysia Terengganu, 21030 Kuala Terengganu, Malaysia; 3. Department of Microbiology, Zhejiang University School of Medicine, 866 YuHuaTang Lu, Hangzhou, Zhejiang, China. Corresponding author: AA Laith, e-mail: laith.abdul@umt.edu.my, Co-authors: MAA: ambak@umt.edu.my, MH: marina@umt.edu.my, SMS: shahreza@umt.edu.my, MN: nadirah@umt.edu.my, ASD: armie@umt.edu.my, WW: wahidah@umt.edu.my, WNWI: fizah_ibrahim89@yahoo.com, ASA: rlya_fiqahaznan@yahoo.com, AJ: golden_pearles@hotmail.com, MNaj: najiah@umt.edu.my Received: 19-07-2016, Accepted: 09-12-2016, Published online: 24-01-2017
\end{abstract}

doi: 10.14202/vetworld.2017.101-111 How to cite this article: Laith AA, Ambak MA, Hassan M, Sheriff SM, Nadirah M, Draman AS, Wahab W, Ibrahim WNW, Aznan AS, Jabar A, Najiah M (2017) Molecular identification and histopathological study of natural Streptococcus agalactiae infection in hybrid tilapia (Oreochromis niloticus), Veterinary World, 10(1): 101-111.

\begin{abstract}
Aim: The main objective of this study was to emphasize on histopathological examinations and molecular identification of Streptococcus agalactiae isolated from natural infections in hybrid tilapia (Oreochromis niloticus) in Temerloh Pahang, Malaysia, as well as to determine the susceptibility of the pathogen strains to various currently available antimicrobial agents.

Materials and Methods: The diseased fishes were observed for variable clinical signs including fin hemorrhages, alterations in behavior associated with erratic swimming, exophthalmia, and mortality. Tissue samples from the eyes, brain, kidney, liver, and spleen were taken for bacterial isolation. Identification of $S$. agalactiae was screened by biochemical methods and confirmed by VITEK 2 and 16S rRNA gene sequencing. The antibiogram profiling of the isolate was tested against 18 standard antibiotics included nitrofurantoin, flumequine, florfenicol, amoxylin, doxycycline, oleandomycin, tetracycline, ampicillin, lincomycin, colistin sulfate, oxolinic acid, novobiocin, spiramycin, erythromycin, fosfomycin, neomycin, gentamycin, and polymyxin B. The histopathological analysis of eyes, brain, liver, kidney, and spleen was observed for abnormalities related to $S$. agalactiae infection.

Results: The suspected colonies of $S$. agalactiae identified by biochemical methods was observed as Gram-positive chained cocci, $\beta$-hemolytic, and non-motile. The isolate was confirmed as $S$. agalactiae by VITEK 2 (99\% similarity), reconfirmed by $16 \mathrm{~S}$ rRNA gene sequencing (99\% similarity) and deposited in GenBank with accession no. KT869025. The isolate was observed to be resistance to neomycin and gentamicin. The most consistent gross findings were marked hemorrhages, erosions of caudal fin, and exophthalmos. Microscopic examination confirmed the presence of marked congestion and infiltration of inflammatory cell in the eye, brain, kidney, liver, and spleen. Eye samples showed damage of the lens capsule, hyperemic and hemorrhagic choroid tissue, and retina hyperplasia accompanied with edema. Brain samples showed perivascular and pericellular edema and hemorrhages of the meninges. Kidney samples showed hemorrhage and thrombosis in the glomeruli and tubules along with atrophy in hematopoietic tissue. Liver samples showed congestion of the sinusoids and blood vessel, thrombosis of portal blood vessel, and vacuolar (fatty) degeneration of hepatocytes. Spleen samples showed large thrombus in the splenic blood vessel, multifocal hemosiderin deposition, congestion of blood vessels, and multifocal infiltration of macrophages.
\end{abstract}

Conclusion: Therefore, it can be concluded that pathological changes in tissues and organs of fish occur proportionally to the pathogen invasion, and because of their high resistance, neomycin and gentamicin utilization in the prophylaxis or treatment of $S$. agalactiae infection should be avoided.

Keywords: 16S rDNA, antibiotic resistance, aquaculture, histopathological examination, polymerase chain reaction, Streptococcus agalactiae.

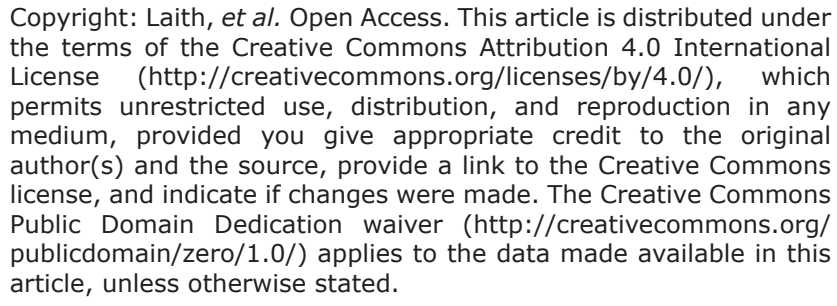
the terms of the Creative Commons Attribution 4.0 International License (http://creativecommons.org/licenses/by/4.0/), which permits unrestricted use, distribution, and reproduction in any medium, provided you give appropriate credit to the original author(s) and the source, provide a link to the Creative Commons license, and indicate if changes were made. The Creative Commons Public Domain Dedication waiver (http://creativecommons.org/ publicdomain/zero/1.0/) applies to the data made available in this article, unless otherwise stated.

\section{Introduction}

Tilapia (Oreochromis niloticus) is described to be among the top cultured fish worldwide including Malaysia [1]. Streptococcus agalactiae is a significant human and animal pathogen [2] with strong association to a variety of diseases, most importantly Streptococcosis, which is a highly problematic 
disease in the aquaculture of freshwater fishes, constantly threatening the sustainability of the global tilapia industry [3]. Periodically, this pathogen has been linked to illness in many others hosts including chickens, camels, dogs, horses, cats, frogs, hamsters, mice, and monkeys. Therefore, not only does $S$. agalactiae compromise food safety but also represent a zoonotic hazard [4].

S. agalactiae infection in tilapia caused a variety of clinical signs to the infected fish. The most common clinical signs of $S$. agalactiae infections in tilapia include erratic swimming (spiraling or spinning), unilateral or bilateral exophthalmia (pop-eye), corneal opacity, eye hemorrhage, and hemorrhages at the base of the fins and opercula. Darkening of the skin, distended abdomen and body curvature, or vertebral deformities have been observed [5-7]. Internally, abnormalities are detected and are grossly visible in the liver, spleen, kidney, eyes, and brain. The affected organs showed enlargement, hemorrhages, inflammation, and ascites $[8,9]$. On the other hand, several affected fish did show any clinical signs before sudden death $[10,11]$.

Streptococcus spp. is associated with fatal outcomes in tilapia and is the most important fish pathogen in Malaysia today [1]. During the last several years, there have been copious $S$. agalactiae infection outbreaks and were documented in numerous farms $[12,13]$. S. agalactiae has a mortality rate of $70 \%$ in red tilapia (O. niloticus hybrid) in cages of Kenyir, Pedu, and Pergau Lakes [1,6]. Unfortunately, little information is available describing the evolution of histological lesions in Tilapia infected naturally by $S$. agalactiae. Thus, this study was conducted for the purpose of isolation and identification of the most prevalent bacteria causing septicemic diseases in cage-cultured fresh-water fishes in several private farms in Temerloh Pahang, Malaysia; in addition, to try and decrease the economic losses caused by such disease causing pathogens by applying preventative and treatment measures using a drug of choice depending on culture sensitivity test. Therefore, we believe this new work shows veterinarians the events of natural S. agalactiae infection in Tilapia and is helpful in reaching a correct rapid diagnosis whereby they can follow our guide in isolation and identification and the proper application of medicine to face economic losses. Finally, this research project will also help researchers to compare or confirm our result, especially with histopathology data.

\section{Material and Methods}

\section{Ethical approval}

This study was carried out in accordance with the guidelines of the International Animal Ethics Committee and is in accordance with local laws and regulations. Adequate measures were taken to minimize discomfort of our animal subjects.

\section{Experimental fish}

Ten apparently naturally infected hybrid tilapia (O. niloticus) weighing 200-300 g were collected from farm ponds in Temerloh Pahang Province, Malaysia. Then, the disease signs were observed and recorded. 10 fish with clinical signs were transferred alive in plastic bags with an oxygen supply to the Fish Health Laboratory (AQUATROP) in University Malaysia Terengganu for further study. The fish was anesthetized with Tricaine Methanesulfonate (MS-222), dissected [14] and submitted to autopsy.

\section{Bacterial isolates}

Samples were taken for routine bacteriological examination from; eye, brain, liver, spleen, and kidney of hybrid tilapia $(O$. niloticus $)$. They were then inoculated onto brain heart infusion (BHI) agar (Merck, Germany) and incubated at $30^{\circ} \mathrm{C}$ for $24 \mathrm{~h}$. The dominant colonies were subcultured on the same media to check the purity of the isolate. After incubation at $30^{\circ} \mathrm{C}$ for $24 \mathrm{~h}$, bacterial colonies were picked and plated on blood agar (MERCK, Germany) plates until pure cultures were obtained. Pure stock isolates were stored at $-20^{\circ} \mathrm{C}$ in $15 \%$ glycerol (final concentration) supplied with BHI broth.

\section{Biochemical characteristics of the isolates}

Biochemical characteristics of the isolates were confirmed by microbial biochemical identification basis of standard phenotypic testing criteria, Gramstain, motility, oxidase activity, growth characteristics, and hemolysis test. The phenotypic systems examined in this study using the VITEK 2 Systems Version: 5.04 ID card (BioMérieux, Inc., Hazelwood, MO) with reference to Berger's Manual of Determinative Bacteriology [15].

\section{Growth characteristics of the isolates}

Growth characteristics of the isolates performed with minor modifications according to Buller [16].

\section{Effect of temperature}

About $25 \mu 1$ of fresh bacterial suspension was inoculated into test tubes filled with $5 \mathrm{ml}$ sterile on BHI broth (MERCK, Germany) and incubated at 5, $10,15,25,30,35,40$ and $45^{\circ} \mathrm{C} .10$ tubes were maintained at each temperature post-inoculation. After $18 \mathrm{~h}$, all the cultures were sampled, and $\mathrm{OD}_{610}$ values were determined.

\section{Effect of pH}

The $\mathrm{pH}$ range of sterile nutrient broth was adjusted to $3,4,5,6,7,8,9,10$ and 11 . For each $\mathrm{PH}, 10$ tubes filled with $5 \mathrm{ml}$ sterile on BHI broth (MERCK, Germany) were prepared, inoculated with $25 \mu \mathrm{l}$ of fresh bacterial suspension and incubated at $30^{\circ} \mathrm{C}$. After $18 \mathrm{~h}$, all the cultures were sampled, and $\mathrm{OD}_{610}$ values were determined.

\section{Effect of salinity}

The salinity range of sterile on $\mathrm{BHI}$ broth (MERCK, Germany) was adjusted to $0 \%, 0.5 \%, 1 \%$, $1.5 \%, 2 \%, 2.5 \%, 3 \%, 3.5 \%, 4 \%, 4.5 \%, 5 \%, 5.5 \%$ and 
$6 \% \mathrm{NaCl}(\mathrm{w} / \mathrm{v})$ for each salinity, 10 tubes filled with $5 \mathrm{ml}$ sterile nutrient broth were prepared, and $25 \mu \mathrm{l}$ of fresh bacterial suspension was inoculated into them. They were statically incubated at $30^{\circ} \mathrm{C}$, and after $18 \mathrm{~h}$, all the cultures were sampled, and $\mathrm{OD}_{610}$ values were determined.

\section{Molecular approaches}

The identified $S$. agalactiae from the eye was subjected to $16 \mathrm{~S}$ rRNA gene polymerase chain reaction (PCR) amplification by universal primers for confirmation of $S$. agalactiae [17].

\section{Bacterial culture and DNA extraction}

The isolate was cultured in $3 \mathrm{ml}$ of Tryptic soya broth (TSB) (MERCK, Germany) overnight at $37^{\circ} \mathrm{C}$. The bacterial culture was centrifuged $(14,000 \times g$ for $5 \mathrm{~min}$ at room temperature), pellet was harvested, and total genomic DNA (gDNA) of the isolates was extracted using Wizard ${ }^{\circledR}$ gDNA Purification Kit, A1120 (Promega, USA) according to manufacturer's protocol for gram positive bacteria. The extracted DNA was used as the template for PCR [18]. PCR

The PCR reaction mixture of $16 \mathrm{~s}$ rRNA was done in $25 \mu 1$ total reaction using $\times 2$ MyTaq mix (Bioline, UK) with $10 \mu \mathrm{M}$ of each primer. Negative control served as non-template mixture [19]. The gDNA of the isolate was amplified for 16S rRNA by bacterial universal primers 8F (5'-GTTTACCTTGTTACGACTT-3') and 1492R (5'-AGAGTTTGATCCTGGATGCTCAG-3'). The PCR reaction was performed in a Biothermal cycler (Bio-Rad, USA) with an initial denaturing step at $95^{\circ} \mathrm{C}$ for $5 \mathrm{~min} ; 26$ cycles of $95^{\circ} \mathrm{C}$ for $30 \mathrm{~s}, 55^{\circ} \mathrm{C}$ for $1 \mathrm{~min}$ and $72^{\circ} \mathrm{C}$ for $2 \mathrm{~min}$; followed by $72^{\circ} \mathrm{C}$ for 10 min. $6 \mu 1$ of the amplified products were electrophoresed by $1.2 \%(\mathrm{w} / \mathrm{v})$ agarose gel in $\times 1 \mathrm{TBE}$ electrophoresis buffer. Standard DNA ladder, 1 and $100 \mathrm{bp}$ (Invitrogen, Germany) were used to confirm the size of the amplified PCR products at $1500 \mathrm{bp}$. The gel was stained with ethidium bromide (Promega, USA) and documented by UV-transilluminator (Bio-Rad, USA). Sequences obtained were analyzed and compared with sequences from GenBank using BLAST NCBI citation (http://blast.ncbi.nlm.nih.gov). The accession number of the $S$. agalactiae was deposited in GenBank.

\section{Antibiotic susceptibility}

Antimicrobial susceptibility test was conducted to further understand the exposure of the strain toward antibiotics by standard antibiotics disc and disc diffusion technique [20]. A suspension $(100 \mu \mathrm{l})$ of fresh cultured of $S$. agalactiae $<24 \mathrm{~h}$ on TSB, diluted to a turbidity equivalent to a MacFarland No. 0.5 standard solution, was spread onto triplicate Mueller-Hinton agar (Oxoid, England) plates, and tested against 18 chemotherapeutic agent discs namely nitrofurantoin (F - 50 $\mu \mathrm{g}$ ), flumequine (UB - $30 \mu \mathrm{g}$ ), florfenicol (FFC - $30 \mu \mathrm{g}$ ), amoxylin (AML - $25 \mu \mathrm{g}$ ), doxycycline (DO - $30 \mu \mathrm{g})$, oleandomycin (OL - $15 \mu \mathrm{g})$, tetracycline
(TE - $30 \mu \mathrm{g}$ ), ampicillin (AMP - $10 \mu \mathrm{g}$ ), lincomycin (MY - $15 \mu \mathrm{g}$ ), colistin sulfate (CT - $25 \mu \mathrm{g}$ ), oxolinic acid (OA - $2 \mu \mathrm{g}$ ), novobiocin (NV - $30 \mu \mathrm{g}$ ), spiramycin (SP - $100 \mu \mathrm{g})$, erythromycin (E - $15 \mu \mathrm{g})$, fosfomycin (FOS - $50 \mu \mathrm{g})$, neomycin $(\mathrm{N}-10 \mu \mathrm{g})$, gentamicin (GM - $10 \mu \mathrm{g})$, and polymyxin B (PB - $30 \mu \mathrm{g}$ ) (Oxoid, England). The susceptibility test agars were incubated at $37^{\circ} \mathrm{C}$ for $24 \mathrm{~h}$ and the diameter of inhibition zones around the discs was measured and compared to the standard table for antimicrobial susceptibility provided by CLSI [21].

\section{Histopathological examination}

This is an outbreak case with high mortality in private farms in Temerloh Pahang, Malaysia, and all specimens were infected after inspection. Five samples of moribund fish were randomly selected to the laboratory. The fish was quickly euthanized with (MS$222,60 \mathrm{mg} / \mathrm{L}$ ) dissected and selected organs including liver, spleen, kidney, eye, and brain immediately fixed in $10 \%(\mathrm{v} / \mathrm{v})$ neutral buffered formalin for histopathological examination. Tissues were dehydrated in an ethanol series, infiltrated and embedded in paraffin wax and sectioned on a rotary microtome at $5 \mu \mathrm{m}$. Sections were stained by hematoxylin and eosin and examined under advanced microscope [22].

\section{Results}

\section{Morphologic and biochemical characteristics}

The isolates showed to be Gram-positive cocci bacteria. After incubation on BHI agar (MERCK, Germany) at $30^{\circ} \mathrm{C}$ for $24 \mathrm{~h}$, the colonies appeared to be raised and glossy, with a diameter of 1.5-2.0 mm. Biochemical characteristics of the isolates were consistent with $S$. agalactiae (Tables-1 and 2).

\section{Growth characteristics}

$S$. agalactiae grew in ambient temperature ranging from 5 to $45^{\circ} \mathrm{C}$, but the optimum growth temperature was $30^{\circ} \mathrm{C}$ (Figure-1). S. agalactiae grew at $\mathrm{pH}$ from 3 to 11, and the optimum $\mathrm{pH}$ was 7 (Figure-2). $S$. agalactiae grew at $\mathrm{NaCl}$ content in the medium from $0 \%$ to $5.5 \%(\mathrm{w} / \mathrm{v})$ with an optimum of $0.5 \%$. When $\mathrm{NaCl}$ content exceeded $5.5 \%$, no growth was observed (Figure-3).

Table-1: Biochemical characteristics of S.agalactiae isolated from naturally infected hybrid tilapia (Oreochromis spp).

\begin{tabular}{ll}
\hline Characteristics & Result \\
\hline Gram-stain & Positive \\
Shape & Coccus \\
Motility & Negative \\
Oxidase & Negative \\
Catalase & Negative \\
Starch & Negative \\
Lactose & Negative \\
Esculin & Negative \\
Glucose & Positive \\
Blood hemolysis & $\beta$-hemolytic \\
\hline
\end{tabular}

S. agalactiae $=$ Streptococcus agalactiae 
Table-2: Biochemical characteristics of suspected isolated from naturally infected hybrid tilapia (Oreochromis spp.) using Vitek 2 with $99 \%$ probability of $S$. agalactiae.

\begin{tabular}{|c|c|c|}
\hline Well & Biochemical test & Resul \\
\hline 2 & D-amygdalin (AMY) & - \\
\hline 4 & Phosphatidylinositol phospholipase C (PIPLC) & - \\
\hline 5 & D-xylose (dXYL) & - \\
\hline 8 & Arginine dihydrolase $1(\mathrm{ADH} 1)$ & + \\
\hline 9 & Beta-galactosidase (BGAL) & - \\
\hline 11 & Alpha-glucosidase (AGLU) & - \\
\hline 13 & Ala-Phe-Pro arylamidase (APPA) & - \\
\hline 14 & Cyclodextrin (CDEX) & - \\
\hline 15 & L-aspartate arylamidase (AspA) & - \\
\hline 16 & Beta galactopyranosidase (BGAR) & - \\
\hline 17 & Alha-mannosidase (AMAN) & - \\
\hline 19 & Phosphatase (PHOS) & + \\
\hline 20 & Leucine arylamidase (LeuA) & + \\
\hline 23 & L-proline arylamidase (ProA) & - \\
\hline 24 & Beta glucuronidase (BGURr) & - \\
\hline 25 & Alpha-galactosidase (AGAL) & - \\
\hline 26 & L-pyrrolidonyl-arylamidase (PyrA) & - \\
\hline 27 & Beta-glucuronidase (BGUR) & - \\
\hline 28 & Alanine arylamidase (AlaA) & - \\
\hline 29 & Tyrosine arylamidase (TyrA) & - \\
\hline 30 & D-sorbitol (dSOR) & - \\
\hline 31 & Urease (URE) & - \\
\hline 32 & Polymixin b resistance (POLYB) & + \\
\hline 37 & D-galactose (dGAL) & + \\
\hline 38 & D-ribose (dRIB) & + \\
\hline 39 & L-lactate alkalinization (ILATk) & - \\
\hline 42 & Lactose (LAC) & - \\
\hline 44 & $\mathrm{~N}$-acetyl-d-glucosamine (NAG) & + \\
\hline 45 & D-maltose (dMAL) & + \\
\hline 46 & Bacitracin resistance (BACI) & + \\
\hline 47 & Novobiocin resistance (NOVO) & + \\
\hline 50 & Growth in $6.5 \% \mathrm{NaCl}(\mathrm{NC} 6.5)$ & + \\
\hline 52 & D-mannitol (dMAN) & - \\
\hline 53 & D-mannose (dMNE) & + \\
\hline 54 & Methyl-B-D-glucopyranoside (MBdG) & + \\
\hline 56 & Pullulan (PUL) & - \\
\hline 57 & D-raffinose (dRAF) & - \\
\hline 58 & O/129 resistance (comp. vibrio) (O129R) & - \\
\hline 59 & Salicin (SAL) & - \\
\hline 60 & Saccharose/sucrose (SAC) & + \\
\hline 62 & D-trehalose (dTRE) & + \\
\hline 63 & Arginine dihydrolase $2(\mathrm{ADH} 2 \mathrm{~s})$ & + \\
\hline 64 & Optochin resistance (OPTO) & + \\
\hline
\end{tabular}

S. agalactiae $=$ Streptococcus agalactiae

\section{S rRNA gene sequence analysis}

The PCR product of the isolate was analyzed at the amplified fragments of approximately $1500 \mathrm{bp}$ in size (Figure-4). The $16 \mathrm{~S}$ rRNA sequence of the isolate was analyzed via BLAST network services. Sequence alignments with known sequences in the GenBank database showed that the brain isolate had high similarity (99\%) to S. agalactiae isolated from China (Accession No. KU561093). The sequencing result of the isolate showed the sequence length of the PCR product was at $1201 \mathrm{bp}$ and was deposited in GenBank (Accession No. KT869025).

\section{Antibiotic susceptibility test}

The results are presented in Table- 3 shows the sensitivity of the $S$. agalactiae strain tested, which exhibited resistance to neomycin and gentamicin; whereas was sensitive to 16 antimicrobial agents.

\section{Histopathology \\ Clinical signs and postmortem lesions}

Most symptoms and clinical abnormalities including loss of appetite, orientation and erratic swimming, mortalities reached about $40 \%$ after $3^{\text {rd }}$ day from clinical abnormalities and sudden death. Postmortem examination of sacrificed fish revealed some fish exhibited hemorrhagic caudal fins, ophthalmic abnormalities including eye opacity and Some fish showed enlarged congested spleen and kidney. In addition, some fish showed heavy hemorrhages on the lip and mouth, severe congestion and congestive kidneys with bloody hemorrhagic ascetic fluids that were noticed on opening the fish as a black color fluid in abdomen (Figures-5-7).

\section{Histopathological examination results}

Specimens were obtained from eye, brain, liver, kidney, and spleen of hybrid tilapia (O. niloticus) naturally infected by $S$. agalactiae revealed histological alterations was variable degrees of intensity. The eye lesions were characterized by damage of lens capsule and aqueous cavity. In addition to hyperplasia in retina, cellular infiltrate were observed in the choroid tissue with hyperemic lesions and inflammation. Periorbital edema was accompanied by inflammatory cellular infiltration and thrombosis (Figures-8-11). in regarsds to microscopic examination of brain specimens, the examined sections revealed congestion of meningeal vessels along with perivascular edema. Meningitis was an obvious sign characterized by thickening with congested blood vessels and inflammatory cells infiltration. Thus, inflammatory infiltration cell was observed in the cerebral cortex accompanied with variable degrees of neuronal degeneration were observed (Figures-12 and 13). Regarding the examined liver tissue specimens revealed congestion and thrombosis of portal blood vessel accompanied with hepatic sinusoids with marked vacuolar (fatty) degeneration change of hepatocytes. Furthermore, focal areas of inflammatory cells infiltration were noticed in hepatic tissue of fish (Figures-14 and 15). Concerning renal alterations, it was characterized by hemorrhage and thrombosis in glomeruli and tubules as well as infiltration of inflammatory cell and atrophy in hematopoietic tissue (Figures-16 and 17). In regards to the histopathological changes that were observed in the examined sections of spleen of the fish, it revealed vascular congestion surrounding with the inflammatory cells infiltration. On the other hand, thrombosis of the splenic blood vessels was clearly seen together with an increase in the melanomacrophage center in the splenic parenchyma (Figures-18 and 19). Histologically, the affected fish by $S$. agalactiae showed congestion, 


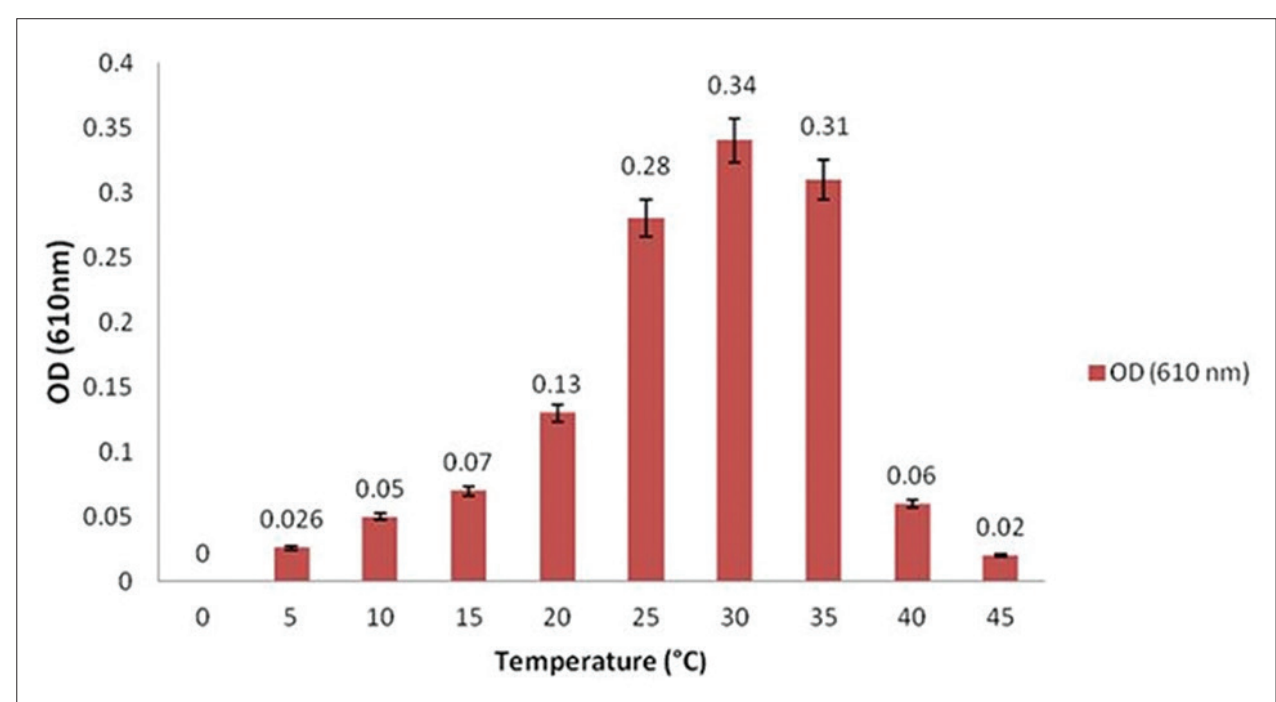

Figure-1: Effect of temperature on the growth of Streptococcus agalactiae.

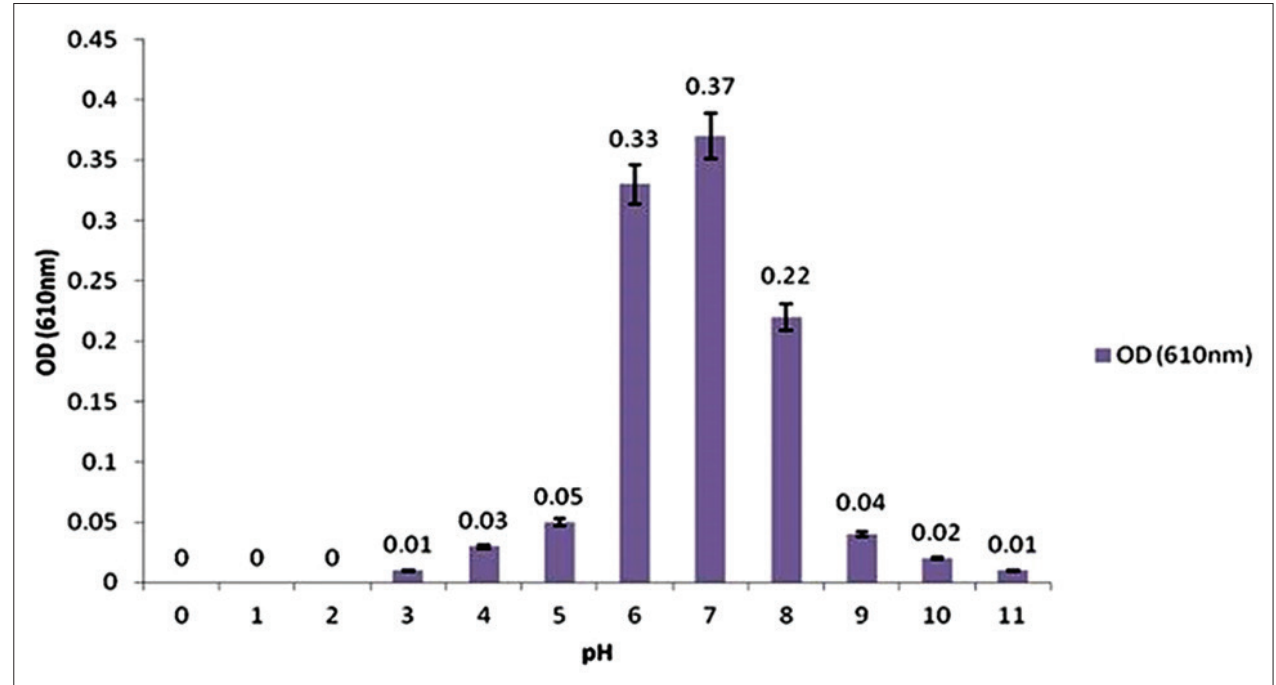

Figure-2: Effect of $\mathrm{pH}$ on the growth of Streptococcus agalactiae.

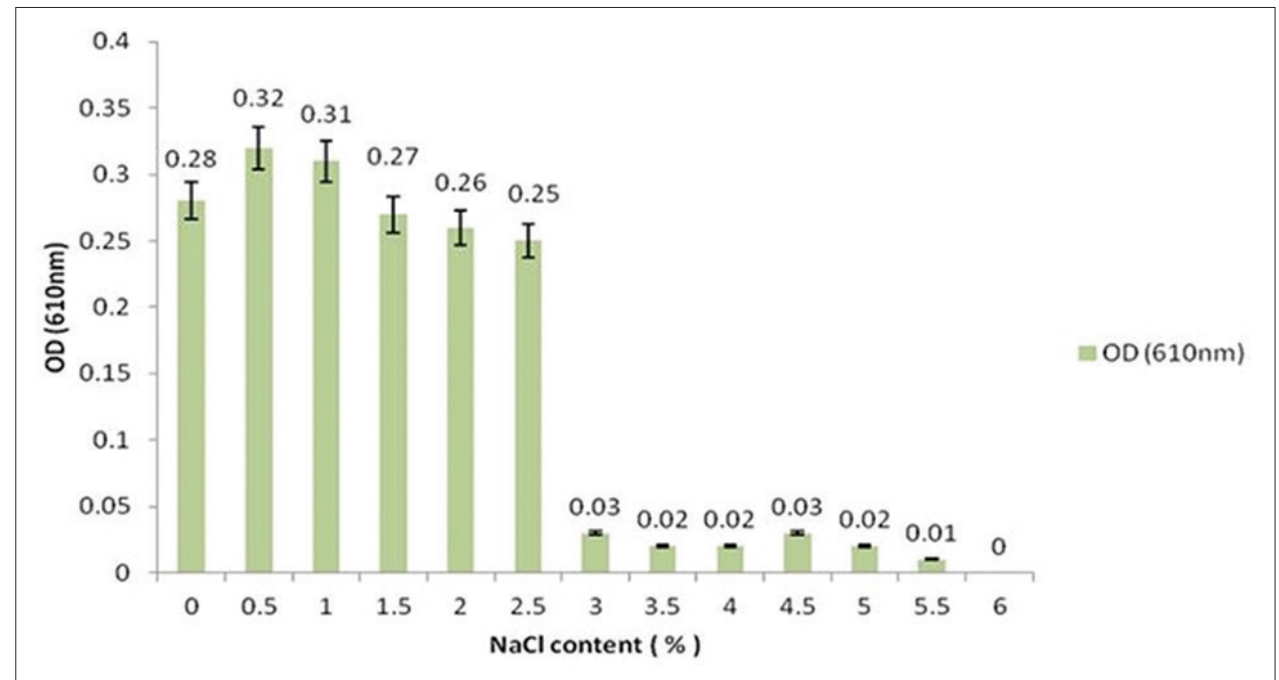

Figure-3: Effect of salinity on the growth of Streptococcus agalactiae.

hemorrhages and inflammation in several internal organs, particularly the liver, heart, spleen, kidney, eyes, and brain as systemic phase of the septicemia disease.

\section{Discussion}

Tilapia (O. niloticus) is a key species being cultured in Malaysia and other South East Asian countries that are high-priced and popular. In the last decades, 


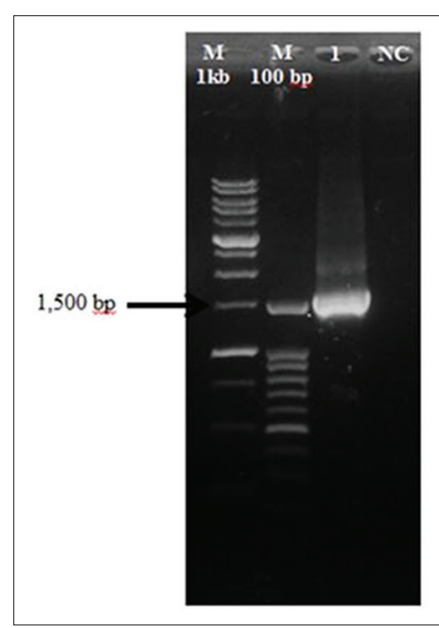

Figure-4: 16S rRNA polymerase chain reaction product of Streptococcus agalactiae (Lane 1) amplified at $1500 \mathrm{bp}$ with standard molecular weight marker (M 1 kb; M 100 bp) and negative control (NC).

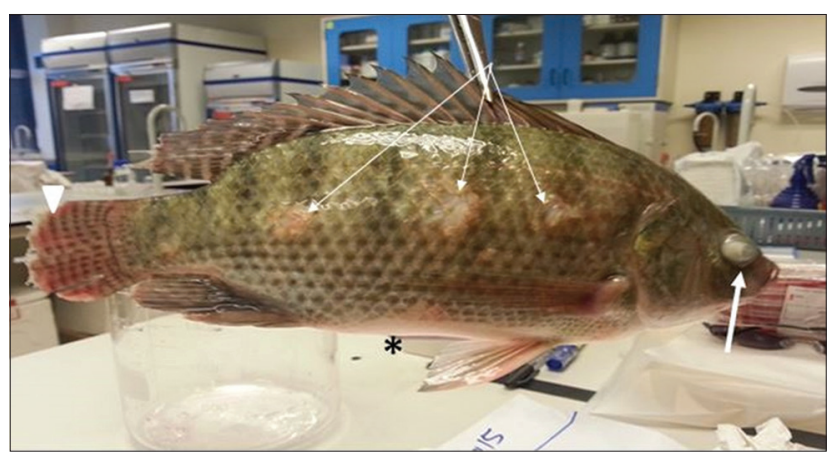

Figure-5: Hybrid tilapia (Oreochromis spp.) naturally infected by Streptococcus agalactiae showing ocular opacity (thick arrow), caudal fin hemorrhage and erosion (arrow head), erosion of the skin (thin arrow), and abdominal distention) (asterisk).

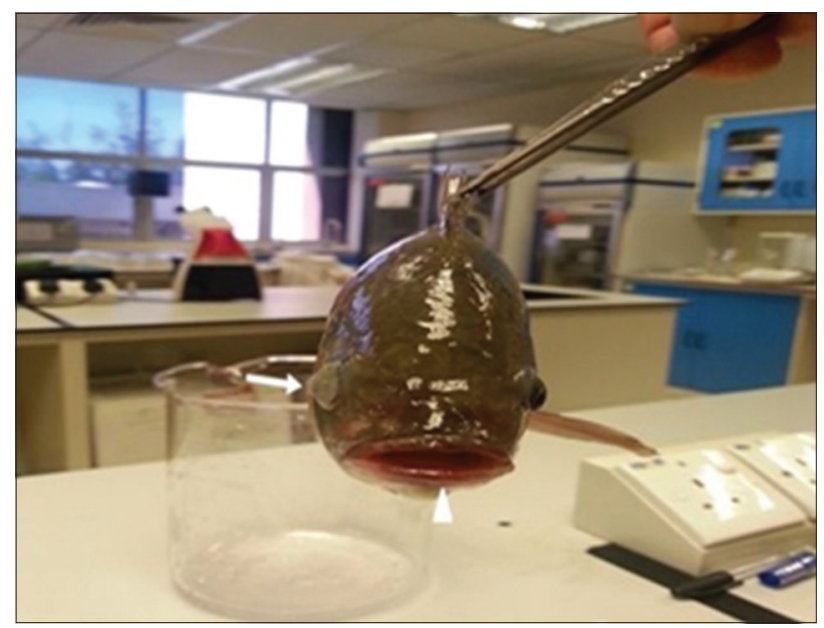

Figure-6: Hybrid tilapia (Oreochromis spp) naturally infected by Streptococcus agalactiae showing unilateral exophthalmia (thick arrow), and heavy hemorrhages on the lip and mouth (arrow head).

many cultured tilapia species have become susceptible to Streptococcosis, an aggressive disease constantly threatening the sustainability of the global tilapia industry $[3,7,12,23]$. This disease is characterized
Table-3: Antimicrobial susceptibility test of $S$. agalactiae isolated from hybrid tilapia (Oreochromis spp.) via agar disc diffusion method.

\begin{tabular}{lcllcc}
\hline Antibiotic & $\begin{array}{c}\text { Disc } \\
\text { potency } \\
(\boldsymbol{\mu g )}\end{array}$ & $\begin{array}{l}\text { Bacteria } \\
\text { (S.agalactiae) }\end{array}$ & \multicolumn{3}{c}{$\begin{array}{c}\text { Zone of } \\
\text { inhibition* }\end{array}$} \\
\cline { 4 - 6 } & & & $\mathbf{R}$ & $\mathbf{I}$ & $\mathbf{S}$ \\
\hline Nitrofurantoin & 50 & $\mathrm{I}$ & 19 & $20-25$ & 26 \\
Flumequine & 30 & $\mathrm{~S}$ & 15 & $16-18$ & 21 \\
Florfenicol & 30 & $\mathrm{~S}$ & 14 & $15-17$ & 18 \\
Amoxylin & 25 & $\mathrm{~S}$ & 13 & $14-17$ & 18 \\
Doxycycline & 30 & $\mathrm{~S}$ & 14 & $15-18$ & 19 \\
Oleandomycin & 15 & $\mathrm{~S}$ & 12 & $13-16$ & 17 \\
Tetracycline & 30 & $\mathrm{~S}$ & 14 & $15-18$ & 19 \\
Ampicillin & 10 & $\mathrm{~S}$ & 14 & $15-16$ & 17 \\
Lincomycin & 15 & $\mathrm{~S}$ & 14 & $15-20$ & 21 \\
Colistin sulfate & 25 & $\mathrm{~S}$ & 8 & $9-10$ & 11 \\
Oxolinic acid & 2 & $\mathrm{~S}$ & 14 & $15-17$ & 18 \\
Novobiocin & 30 & $\mathrm{I}$ & 17 & $18-21$ & 22 \\
Spiramycin & 100 & $\mathrm{~S}$ & 12 & $13-15$ & 16 \\
Erythromycin & 15 & $\mathrm{~S}$ & 13 & $14-22$ & 23 \\
Fosfomycin & 50 & $\mathrm{~S}$ & 13 & $14-16$ & 17 \\
Neomycin & 10 & $\mathrm{R}$ & 12 & $13-15$ & 17 \\
Gentamicin & 10 & $\mathrm{R}$ & 12 & $13-14$ & 15 \\
Polymyxin B & 300 & $\mathrm{~S}$ & 8 & $9-11$ & 12 \\
\hline
\end{tabular}

*Susceptible (S), Intermediate susceptible (I),

Resistant (R). S. agalactiae=Streptococcus agalactiae

grossly by hemorrhages and hyperemia, especially of the fins, unilateral exophthalmos with intraocular hemorrhages, kidney enlargement, as well as high mortality. The aim of this study was to use molecular approaches to investigate the relative contributions of composition of hybrid tilapia (O. niloticus) naturally infected by $S$. agalactiae with histopathological emphasis on lesions in eye, brain, kidney, liver, and spleen. Histopathological examination provides a methodological platform to determine the effect of bacteria in various organs [1]. In addition, using PCR methods have shown to be very reliable in the detection of $S$. agalactiae as well as a vast reduction in time in comparison with culture methods [24]. Most new research depends on biochemical and molecular methods for identifying and characterizing bacteria. This study was done using standardized set of biochemical identification and confirmed by molecular approaches (16S rRNA gene PCR) to the isolated bacteria. Hence, we have not focused on the pathogenicity of these bacteria in this study.

In this study, $S$. agalactiae were isolated from the eye of diseased fish hybrid tilapia (O. niloticus). S. agalactiae, which is considered the main etiological agent of clinical diseases in healthy fish, is a pathogen of interest to several researchers whose works all involve the pathogenicity of $S$. agalactiae in causing disease in fish $[8,12,25,26]$. The hybrid tilapia (O. niloticus) naturally infected by $S$. agalactiae revealed several clinical manifestations consistent with the disease including; erratic swimming, corneal opacity, hemorrhage of the fin and internal organs. Histopathological abnormalities observed in the brain, kidney and eye tissues are suggestive of septicemia as observed in natural and 


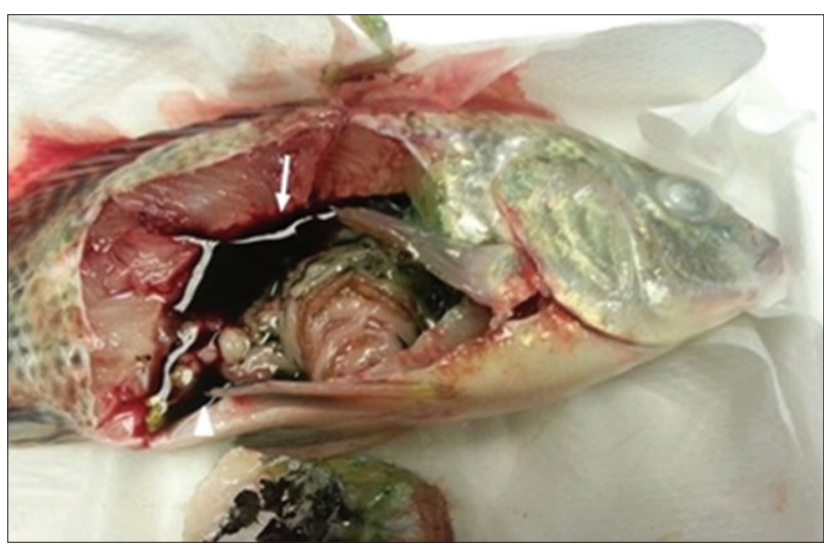

Figure-7: Hybrid tilapia (Oreochromis spp) naturally infected by Streptococcus agalactiae showing septicemic lesions with severe organ congestion, congestive kidneys (thick arrow), and bloody hemorrhagic ascetic fluids that were noticed on dissection (arrow head).

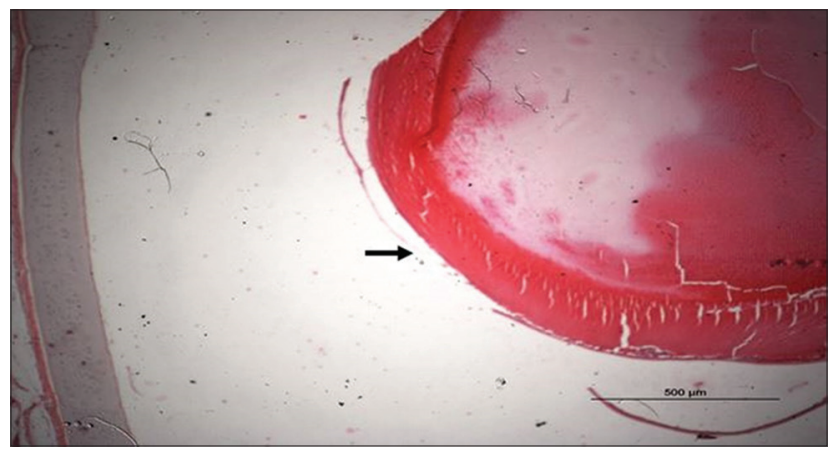

Figure-8: Eye section ( $\mathrm{H}$ and $\mathrm{E}$ stain) of hybrid tilapia (Oreochromis spp.) naturally infected by Streptococcus agalactiae showing damage of lens capsule (arrow).

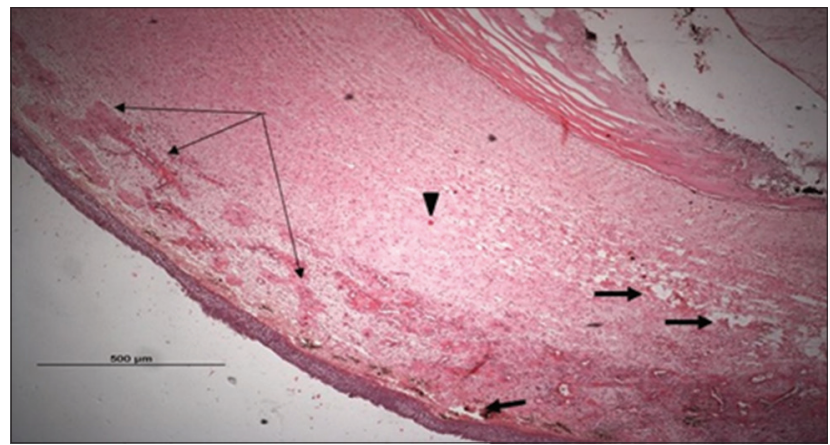

Figure-9: Eye section ( $\mathrm{H}$ and $\mathrm{E}$ stain) of hybrid tilapia (Oreochromis spp.) naturally infected by Streptococcus agalactiae showing choroid edema (thick arrow), hyperemic choroid (thin arrow), and hemorrhage (arrow head).

experimental Streptococcal infection $[5,8,17,23,27,28]$. Meanwhile, Yiagnisis and Athanassopoulou [29] stated that clinical manifestations caused by any pathogen are dependent upon certain factors including the type of host, age of organism, and the stage of disease (acute or chronic). Furthermore, in several cases, there can be no correlation found between internal and external damages. There are cases in which systemic diseases with high mortality rates caused extensive internal damage to infected fish, but often appearing healthy. On the other hand, several diseases with a relatively

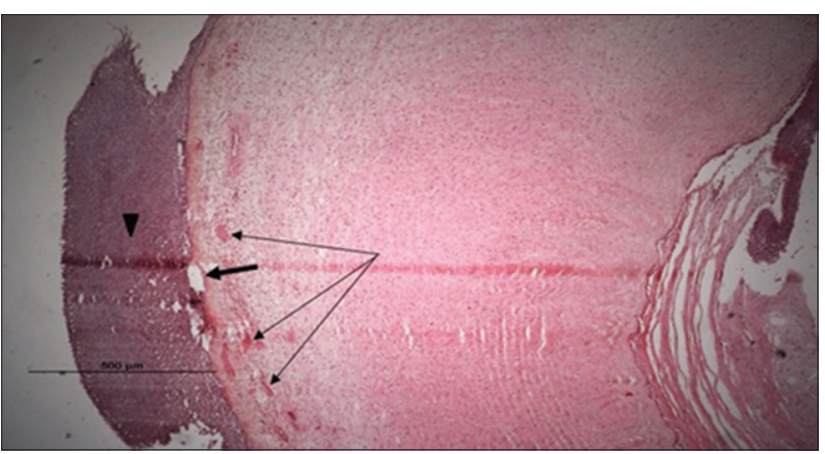

Figure-10: Eye section ( $\mathrm{H}$ and $\mathrm{E}$ stain) of hybrid tilapia (Oreochromis spp.) naturally infected by Streptococcus agalactiae showing retina hyperplasia (arrow head), choroid hemorrhage (thin arrow), and choroid edema (thick arrow).

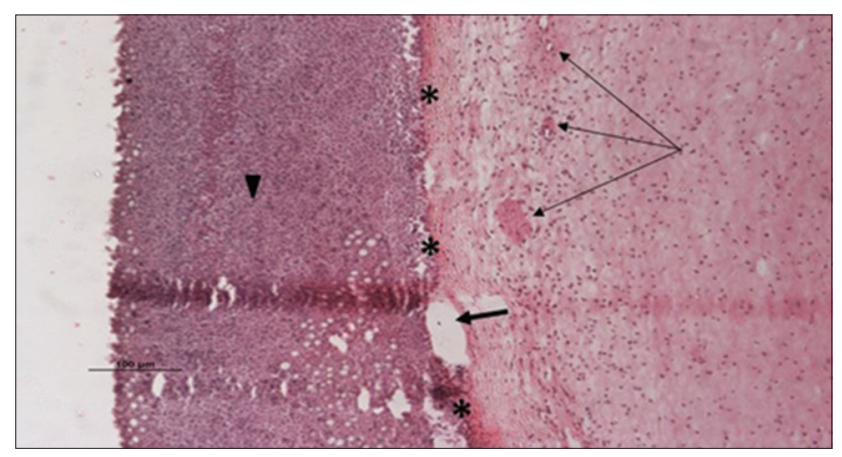

Figure-11: Eye section ( $\mathrm{H}$ and $\mathrm{E}$ stain) of hybrid tilapia (Oreochromis spp.) naturally infected by Streptococcus agalactiae showing retina hyperplasia (arrow head), retina edema (thick arrow), choroid hemorrhage (thin arrow), and choroid edema (asterisk) with inflammatory cellular infiltration.

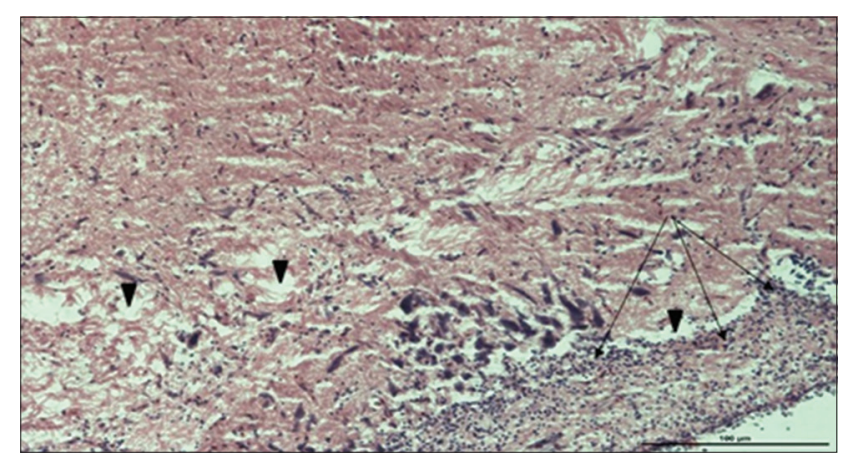

Figure-12: Brain section ( $\mathrm{H}$ and $\mathrm{E}$ stain) of hybrid tilapia (Oreochromis spp.) naturally infected by Streptococcus agalactiae showing infiltration of inflammatory cell (thin arrow), perivascular and pericellular edema (head arrow).

low mortality are capable of causing significant damage such as ulcers, necrosis, and exophthalmos, rendering those fish unfit for consumer sales. The gross pathological abnormalities were typical manifestations of acute septicemia, as in agreement with Netto et al. [25] and Mian et al. [30] who concluded that $S$. agalactiae is characterized by septicemia and meningoencephalitis in fish. Furthermore, fish bacterial infections can arise as a septicemia where bacteria and its extracellular products exist in the circulatory system disrupting fish physiological functions and induce variety of 


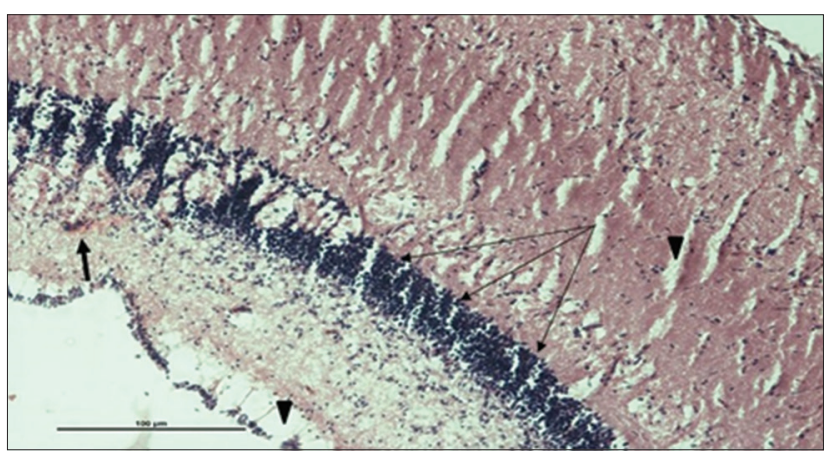

Figure-13: Brain section ( $\mathrm{H}$ and $\mathrm{E}$ stain) of hybrid tilapia (Oreochromis spp.) naturally infected by Streptococcus agalactiae showing infiltration of inflammatory cell (thin arrow), perivascular and pericellular edema (head arrow), and hemorrhages (thick arrow) of the meninges.

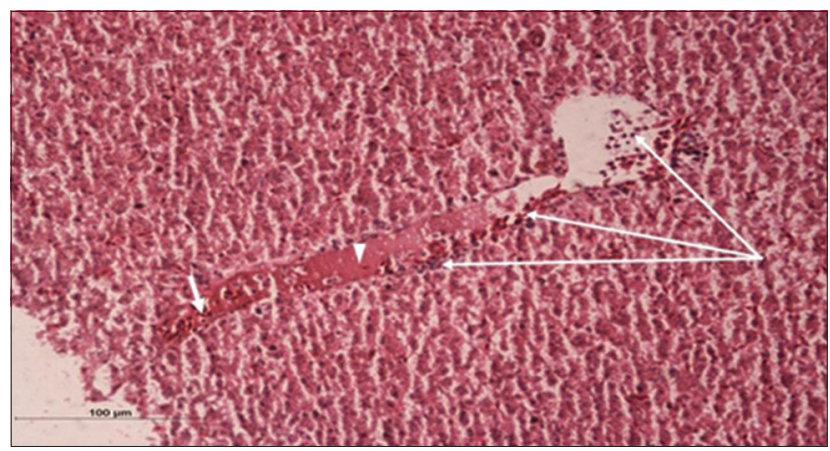

Figure-14: Liver section ( $\mathrm{H}$ and $\mathrm{E}$ stain) of hybrid tilapia (Oreochromis spp.) naturally infected by Streptococcus agalactiae showing congestion of blood vessel (thick arrow), thrombosis of portal blood vessel (head arrow), and inflammatory cells infiltration (thin arrow).

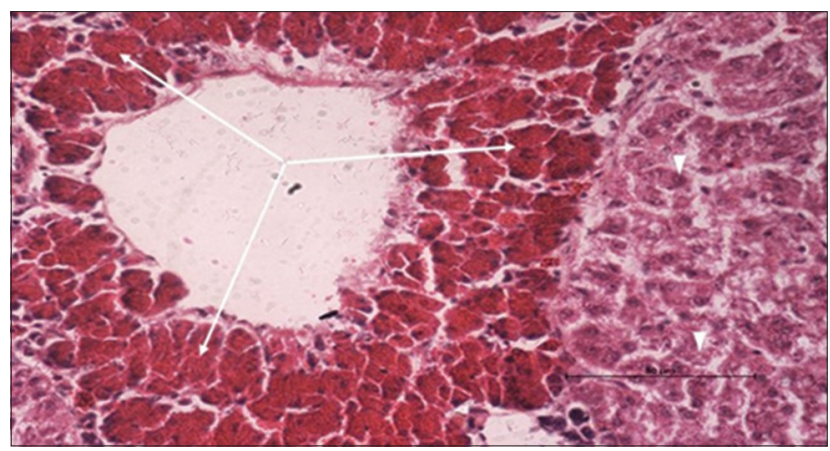

Figure-15: Liver section ( $\mathrm{H}$ and $\mathrm{E}$ stain) of hybrid tilapia (Oreochromis spp.) naturally infected by Streptococcus agalactiae showing congestion of sinusoids and loss of hepatocytes (thin arrow), and vacuolar (fatty) degeneration of hepatocytes (head arrow).

pathological alterations that may lead to death. Thus, sudden death may be due to acute systemic infection of natural infection by S. agalactiae [12]. Studies of eye lesions are usually commonly observed in most of systemic bacterial diseases. Hence, exophthalmia occurred by corneal opacity in fish infected by $S$. agalactiae and histopathological examination showed lesions involving periorbital tissue and choroid in addition to moderate vascular hemorrhage. Our results were in accordance with many researchers who reported exophthalmia in tilapia infected with Streptococcus spp., with

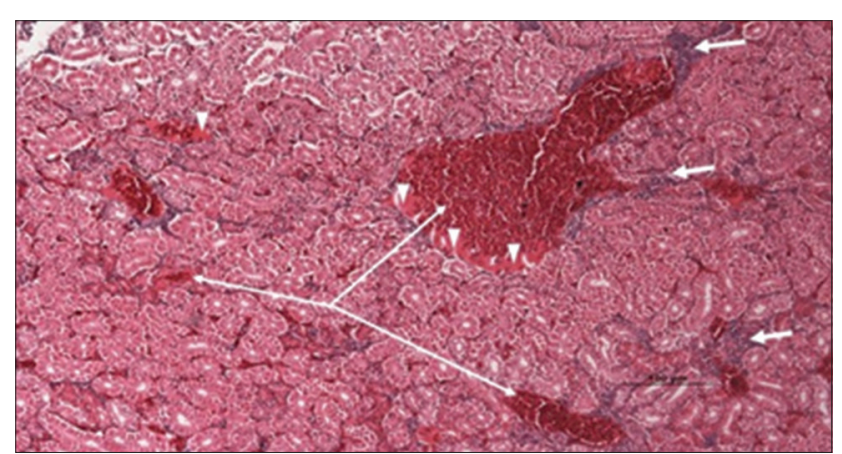

Figure-16: Kidney section (H and E stain) of hybrid tilapia (Oreochromis spp.) naturally infected by Streptococcus agalactiae showing hemorrhage (thin arrow), thrombosis (head arrow) in glomeruli and tubules, and infiltration of inflammatory cell (thick arrow).

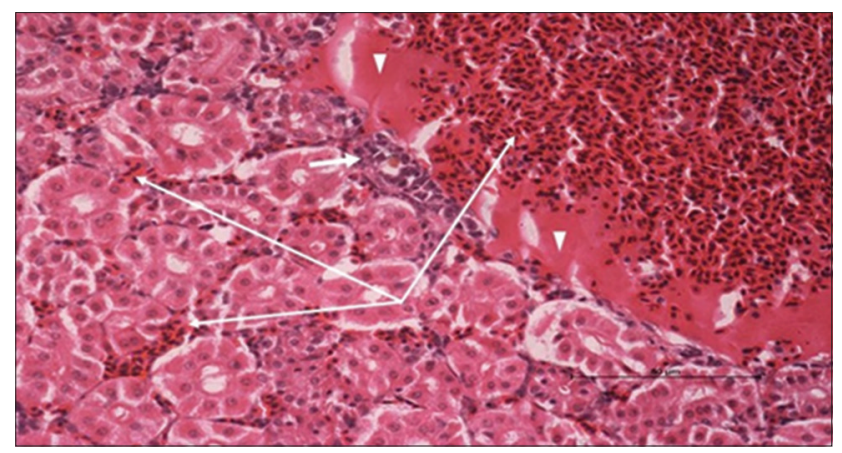

Figure-17: Kidney section ( $\mathrm{H}$ and $\mathrm{E}$ stain) of hybrid tilapia (Oreochromis spp.) naturally infected by Streptococcus agalactiae showing hemorrhage (thin arrow), thrombosis (head arrow) and atrophy in hematopoietic tissue (thick arrow).

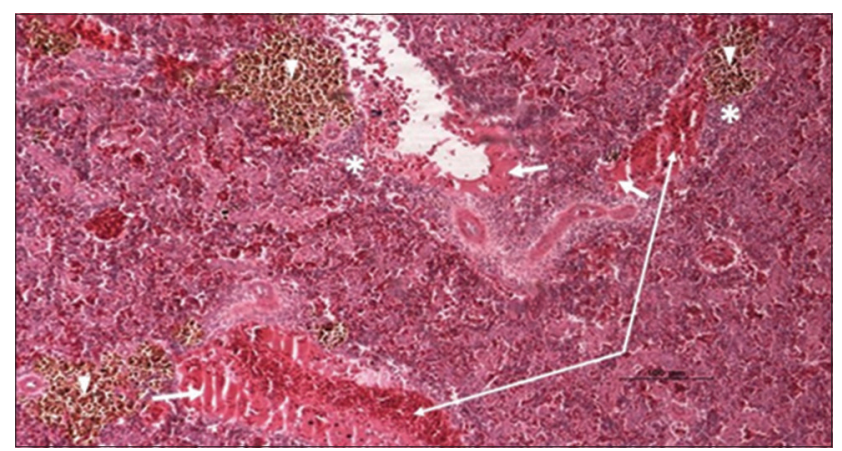

Figure-18: Spleen parenchyma section ( $\mathrm{H}$ and $\mathrm{E}$ stain) of hybrid tilapia (Oreochromis spp.) naturally infected by Streptococcus agalactiae showing large thrombus in the splenic blood vessel (thick arrow), multifocal hemosiderin deposition (head arrow), congestion of blood vessels (thin arrow), and multifocal infiltration of macrophages (asterisk).

lesions being discovered in periorbital and choroid tissue $[5,31,32]$. Histopathological studies of brain tissue specimens show meningeal thickening and inflammatory cell infiltration in the brain tissue, indicating meningitis, accompanied by hemorrhage similar finding reported in various study [7,10,33-35]. These results demonstrated that macrophages can possibly act as a vehicle for $S$. agalactiae, allowing it to cross the bloodbrain barrier and gain access to the central nervous system, thereby becoming disseminated throughout 


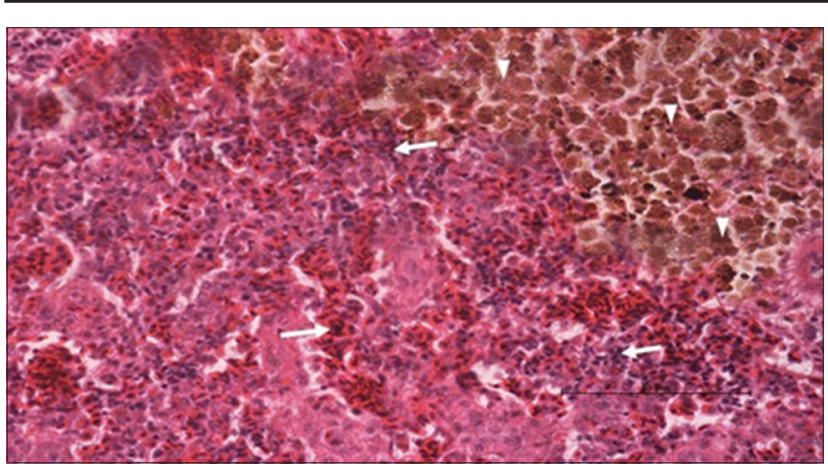

Figure-19: Spleen parenchyma section ( $\mathrm{H}$ and $\mathrm{E}$ stain) of hybrid tilapia (Oreochromis spp.) naturally infected by Streptococcus agalactiae showing increased melanomacrophage cells (head arrow), and inflammatory cells infiltration (thick arrow).

the organism's organ systems initiating bacterial septicemia [36]. The pathological manifestation in the eyes and brain tissue of naturally infected fish correlates with the clinical behavioral abnormalities of erratic pattern of swimming, orientation abnormalities. These results support the theories by several authors who state that $S$. agalactiae is neurotropic [7,28,32,37,38].

The histopathological changes observed in liver revealed marked degeneration of the hepatocytes and congestion in the sinusoid due to the inability of the liver to detoxify the foreign body and resulting in liver dysfunction and eventually death [39]. In addition, S. agalactiae infection in tilapia liver demonstrated vacuolation of hepatocytes with fatty change in response to the reduced blood flow due to congestion of blood vessel and thrombosis of portal blood vessel [32,35,37]. Histological analysis of the kidney in this study was characterized by severe hemorrhage and thrombosis accompanied with infiltration of inflammatory cell, and severe atrophy in hemopoietic tissue similar to the experimental infection in red tilapia (Oreochromis sp.) with $S$. agalactiae $[12,23]$. The histopathological examination of spleen tissues revealed red pulp degeneration, splenic capillary congestion, and focal hemorrhages. Furthermore, large areas of hemosiderin deposits and melanomacrophage center hypertrophy as similarly reported by Filho et al. [32]. The proliferation of the hematopoietic in spleen tissue and activation of the main phagocytic cells, melanomacrophages, may be due to the role of bacteria and its toxins to stimulate the immune response in infected fish [40]. The lesions in the hemopoietic tissue including kidneys and spleen indicated that the $S$. agalactiae infection may suppress the immune system and increasing host susceptibility to infection with other microorganisms.

Resistance to generic antibiotics is a developing issue among Streptococcus spp. [41]. The degree of susceptibility of the $S$. agalactiae toward 18 different types of antibiotics in this study revealed $S$. agalactiae to be resistant to neomycin and gentamicin, which is in accordance with similar result reported by Abuseliana et al. [7] in fish infected with S. agalactiae isolated from red tilapia in Malaysia and to Geng et al. [42] who also described resistance of $S$. agalactiae to gentamicin. Neomycin and gentamicin, which are wide spectrum aminoglycoside antibiotics, work by establishing a binding process to the receptors found on the $30 \mathrm{~S}$ ribosomal subunit of bacteria; therefore, preventing the initiation complex between bacterial messenger RNA and the ribosomal subunit leasing to misreading of the bacterial DNA and formation of nonfunctional proteins thereby affecting its survival.

Several environmental conditions existing during disease progress have been thought to be causative factors in influencing fish to infections such stressors are most commonly associated with high water temperature $[6,13]$, susceptibility of tilapia $[7,12]$, pathogenicity of $S$. agalactiae [7], and the high-density fish culture would all increase the susceptibly of fish to S. agalactiae infections [43].

Hence, the detection of the pathogens described in this study with the emphasis on transmission risk to other farmed fish and the establishment of procedures to improve quarantine and pathogen screening is needed. In addition, it is recommended that generic antibiotics be used with caution in the treatment of fish infections unless antibiotic sensitivity testing can be done. Finally, it is strongly suggested that both PCR assay methods and culture methods be routinely utilized for the accurate detection of $S$. agalactiae in tilapia.

\section{Conclusion}

The findings of this study reveal the need to raise future epidemiological and pathogenesis studies contributing to a greater understanding of the behavior of the bacteria in a population and within the host, in addition to design control strategies. Because most $S$. agalactiae isolates displayed resistance to at least two antibiotics; therefore, molecular procedures should be utilized in determining the antibiotic resistance profiles of the isolates in order to properly control infections. Besides, this study has established that the histopathological changes of Tilapia could be helpful in the diagnosis of the pathological and physiological standings in Tilapia culture.

\section{Authors' Contributions}

AAL conducted the design of the experiment. AAL, MAA, MH, SMS, ASD, WW, and AJ involved in the field and laboratory work for data collection. WNWI and ASA, contributed in the confirmation of Streptococcus agalactiae by 16s rRNA gene sequencing. AAL and WNWI involved in data analysis. MN deposited the accession number of Streptococcus agalactiae in GenBank. AAL, WNWI, MNaj with the help of AJ analyzed and reviewed the manuscript. All authors read and approved the final manuscript.

\section{Acknowledgments}

Author deeply acknowledges everyone from the Institute of Tropical Aquaculture (Aquatrop) Universiti Malaysia Terengganu for their discussion 
and support. This work was supported by the research grant from the Ministry of Higher Education, Malaysia [FRGS 1/2015/FG03/UMT/03/2 Number: 59385].

\section{Competing Interests} interest.

The authors declare that they have no competing

\section{References}

1. Marcel, G., Sabri, M.Y., Siti-Zahrah, A. and Emikpe, O.B. (2013) Water condition and identification of potential pathogenic bacteria from red tilapia reared in cage-cultured system in two different water bodies in Malaysia. Afr. $J$. Microbiol. Res., 7(47): 5330-5337.

2. Ma, Y.P., Ke, H., Liang, Z.L., Liu, Z.X., Hao, L., Ma, J.Y. and Li, Y.G. (2016) Multiple evolutionary selections involved in synonymous codon usages in the Streptococcus agalactiae Genome. Int. J. Mol. Sci., 17(3): 1-12.

3. Pradeep, P.J., Suebsing, R., Sirthammajak, S., Kampeera, J., Jitrakorn, S., Saksmerprome, V., Turner, W., Palang, I., Vanichviriyakit, R., Senapin, S., Jeffs, A., Kiatpathomchai, W. and Withyachumanarnkul, B. (2016) Evidence of vertical transmission and tissue tropism of Streptococcosis from naturally infected red tilapia (Oreochromis spp.). Aquac. Rep., 3: 58-66.

4. Pereira, U.P., Mian, G.F., Oliveira, I.C.M., Benchetrit, L.C., Costa, G.M. and Figueiredo, H.C.P. (2010) Genotyping of Streptococcus agalactiae strains isolated from fish, human and cattle and their virulence potential in nile tilapia. Vet. Microbiol., 140: 186-192.

5. Austin, B. and Austin, D.A., editors. (1999) Bacterial Fish Pathogens Diseases of Farmed and Wild Fish. $4^{\text {th }}$ ed. Praxis Publishing, Chichester, UK.

6. Siti-Zahrah, A., Padilah, B., Azila, A., Rimatulhana, R. and Shahidan, H. (2008) Multiple streptococcal species infection in cage-cultured red tilapia but showing similar clinical signs. In: Bondad-Reantaso, MG., Mohan, CV., Crumlish, M., Subasinghe, RP., editors. Diseases in Asian Aquaculture VI. Manila: Fish Health Section, Asian Fisheries Society; 2008. pp: 313-320.

7. Abuseliana, A., Daud, H., Aziz, S.A., Bejo, S.K. and Alsaid, M. (2010) Streptococcus agalactiae the etiological agent of mass mortality in farmed red tilapia (Oreochromis sp.). J. Anim. Vet. Adv., 9(20): 2640-2646.

8. Musa, N., Wei, L.S., Musa, N., Hamdan, R.H., Leong, L.K., Wee, W., Amal, M.N., Kutty, B.M. and Abdullah, S.Z. (2009) Streptococcosis in red hybrid tilapia (Oreochromis niloticus) commercial farms in Malaysia. Aquac. Res., 40(5): 630-632.

9. Pretto-Giordano, L.G., Müller, E.E., de Freitas, J.C. and da Silva, V.G. (2010) Evaluation on the pathogenesis of Streptococcus agalactiae in nile tilapia (Oreochromis niloticus). Braz. Arch. Biol. Technol., 53(1): 87-92.

10. Rodkhum, C., Kayansamruaj, P. and Pirarat, N. (2011) Effect of water temperature on susceptibility to Streptococcus agalactiae serotype Ia infection in nile tilapia (Oreochromis niloticus). Thai. J. Vet. Med., 41(3): 309-314.

11. Ye, X., Li, J., Lu, M., Deng, G., Jiang, X., Tian, Y., Quan, Y. and Jian, Q. (2011) Identification and molecular typing of Streptococcus agalactiae isolated from pond-cultured tilapia in China. Fish. Sci., 77(4): 623-632.

12. Zamri-Saad, M., Amal, M.N. and Siti-Zahrah, A. (2010) Pathological changes in red tilapias (Oreochromis spp.) naturally infected by Streptococcus agalactiae. J. Comp. Pathol., 2-3: 227-229.

13. Najiah, M., Aqilah, N.I., Lee, K.L., Khairulbariyyah, Z., Mithun, S., Jalal, K.C.A., Shaharom, H.F. and Nadirah, M. (2012) Massive mortality associated with Streptococcus agalactiae infection in cage-cultured red hybrid tilapia Oreochromis niloticus in Como River, Kenyir Lake,
Malaysia. J. Biol. Sci., 12(8): 438-442.

14. Jolaine, M.W., Ralph, M.B. and Anthony, J.C. (2009) Evaluation of rapid cooling and tricaine methanesulfonate (MS222) as methods of euthanasia in zebrafish (Danio rerio). J. Am. Assoc. Lab. Anim. Sci., 48(6): 785-789.

15. Breed, S.R., Murray, E.G.D. and Smith, N.R. (1957) Bergey's Manual of Determinative Bacteriology. $7^{\text {th }}$ ed. The Williams \& Wilkins Company, USA. p1-194.

16. Buller, N.B. (2004) Bacteria from Fish and Other Aquatic Animals: A Practical Identification Manual. CABI Publishing, Alabama, USA. p1-361.

17. Evans, J.J., Pasnik, D.J., Klesius, P.H. and Al-Ablani, S. (2006) First report of Streptococcus agalactiae and Lactococcus garvieae from a wild bottlenose folphin (Tursiops truncatus). J. Wildl. Dis. Assoc., 42(3): 561-569.

18. Yang, Y., Liu, Y., Ding, Y., Yi, L., Ma, Z., Fan, H. and Lu, C. (2013) Molecular characterization of Streptococcus agalactiae isolated from bovine mastitis in Eastern China. PLoS One, 8(7): 1-8.

19. Fay, A.B., Corrigan, J. and Murphy, R.A. (2016) Shortterm effects of mechanical drainage on fungal and bacterial community structure in a managed grassland soil. Appl. Soil Ecol., 101: 93-100.

20. Bauer, A.W., Kirby, W.M., Sherris, J.C. and Turck, M. (1966) Antibiotic susceptibility testing by a standardized single disk method. Am. J. Clin. Pathol., 45(4): 493-496.

21. CLSI. (2012) Performance Standards for Antimicrobial Susceptibility Testing; Twenty-Second Informational Supplement. Vol. 32. Clinical and Laboratory Standards Institute, Wayne, PA. p1-184.

22. Al-Darwesh, A.A., Al-Shabbani, M.A.A. and Faris, B.H. (2014) Diagnostic and pathological study of Argulus japonicus in goldfish (Carassius auratus). Glob. J. BioSci. Biotechnol., 3(4): 384-387.

23. Abdullah, S., Omar, N., Yusoff, S.M., Obukwho, E.B., Nwunuji, T.P., Hanan, L. and Samad, J. (2013) Clinicopathological features and immunohistochemical detection of antigens in acute experimental Streptococcus agalactiae infection in red tilapia (Oreochromis spp.). Springerplus, 2(286): 1-7.

24. Chiang, Y.C., Pai, W.Y., Chen, C.Y. and Tsen, H.Y. (2008) Use of primers based on the heat shock protein genes hsp70, hsp40, and hsp10, for the detection of bovine mastitis pathogens Streptococcus agalactiae, Streptococcus uberis and Streptococcus bovis. Mol. Cell Probes., 22(4): 262-266.

25. Netto, L.N., Leal, C.A.G. and Figueiredo, H.C.P. (2011) Streptococcus dysgalactiae as an agent of septicaemia in nile tilapia, Oreochromis niloticus (L.). J. Fish Dis., 34(3): 251-254.

26. Lukkana, M., Jantrakajorn, S. and Wongtavatchai, J. (2015) Antimicrobial susceptibility and enrofloxacin resistance of Streptococcal bacteria from farmed nile tilapia, Oreochromis niloticus (Linnaeus 1758) in Thailand. Aquac. Res., 47(10): 3136-3144..

27. Suanyuk, N., Kanghear, H., Khongpradit, R. and Supamattaya, K. (2005) Streptococcus agalactiae infection in tilapia (Oreochromis niloticus). Songklanakarin J. Sci. Technol., 27: 307-319.

28. Suanyuk, N., Kong, F., Ko, D., Gilbert, G.L. and Supamattaya, K. (2008) Occurrence of rare genotypes of Streptococcus agalactiae in cultured red tilapia Oreochromis sp. and nile tilapia $O$. niloticus in Thailand-Relationship to human isolates? Aquaculture, 284(1): 35-40.

29. Yiagnisis, M. and Athanassopoulou, F. (2011) Bacteria isolated from diseased wild and farmed marine fish in Greece. Recent Adv. Fish Farms., 27(2): 61-69.

30. Mian, G.F., Godoy, D.T., Leal, C.A.G., Yuhara, T.Y., Costa, G.M. and Figueiredo, H.C.P. (2009) Aspects of the natural history and virulence of $S$. agalactiae infection in nile tilapia. Vet. Microbiol., 136: 180-183.

31. Russo, R., Mitchell, H. and Yanong, R.P.E. (2006) Characterization of Streptococcus iniae isolated from 
ornamental cyprinid fishes and development of challenge models. Aquaculture, 256(1): 105-110.

32. Filho, C.I., Müller, E.E., Pretto-Giordano, L.G. and Bracarense, F.R.L. (2009) Histological findings of experimental Streptococcus agalactiae infecion in nile tilapias (Oreochromis niloticus). Braz. J. Vet. Pathol., 2(1): 12-15.

33. Hernández, E., Figueroa, J. and Iregui, C. (2009) Streptococcosis on a red tilapia, Oreochromis sp., Farm: A case study. J. Fish Dis., 32(3): 247-252.

34. Noraini, O. and Jahwarhar, N.A. (2013) The effect of heat stress on clinicopathological changes and immunolocalization of antigens in experimental Streptococcus agalactiae infection in red hybrid tilapia (Oreochromis Spp.). Vet. World, 6: 997-1003.

35. Suwannasang, A., Dangwetngam, M., Issaro, A., Phromkunthong, W. and Suanyuk, N. (2014) Pathological manifestations and immune responses of serotypes Ia and III Streptococcus agalactiae infections in nile tilapia (Oreochromis niloticus). Songklanakarin J. Sci. Technol., 36(5): 499-506.

36. Bowater, R.O., Forbes-Faulkner, J., Anderson, I.G., Condon, K., Robinson, B., Kong, F., Gilbert, G.L., Reynolds, A., Hyland, S., McPherson, G., Brien, J.O. and Blyde, D. (2012) Natural outbreak of Streptococcus agalactiae (GBS) infection in wild giant Queensland grouper, Epinephelus lanceolatus (Bloch), and other wild fish in Northern Queensland, Australia. J. Fish Dis., 35(3): 173-186.

37. Chen, C.Y., Chao, C.B. and Bowser, P.R. (2007)
Comparative histopathology of Streptococcus iniae and Streptococcus agalactiae-infected tilapia. Bull. Eur. Assoc. Fish Pathol., 27(2): 2-9.

38. Eldar, A., Bejerano, Y., Livoff, A., Horovitcz, A. and Bercovier, H. (1995) Experimental streptococcal meningo-encephalitis in cultured fish. Vet. Microbiol., 43(1): 33-40.

39. Okwari, O.O., Ettarh, R.R., Akpogomeh, B.A. and Eteng, M.U. (2000) Gastric anti-secretory and anti-ulcerogenic effects of Dombeya buettneri in rats. $J$. Ethnopharmacol., 71: 315-319.

40. Koo, H.J., Kwak, H.S., Yoon, S.H. and Woo, G.J. (2012) Phylogenetic group distribution and prevalence of virulence genes in Escherichia coli isolates from food samples in South Korea. World J. Microbiol. Biotechnol., 28(4): 1813-1816.

41. Amyes, S.G.B. (2007) Enterococci and Streptococci. Int. J. Antimicrob. Agents, 29: S43-S52.

42. Geng, Y., Wang, K.Y., Huang, X.L., Chen, D.F., Li, C.W., Ren, S.Y., Liao, Y.T., Zhou, Z.Y., Liu, Q.F., Du, Z.J. and Lai, W.M. (2012) Streptococcus agalactiae, an emerging pathogen for cultured ya-fish, Schizothorax prenanti, in China. Transbound Emerg. Dis., 59(4): 369-375.

43. Wang, K., Chen, D., Huang, L., Lian, H., Wang, J., Xiao, D., Geng, Y., Yang, Z. and Lai, W. (2013) Isolation and characterization of Streptococcus agalactiae from nile tilapia Oreochromis niloticus in China. Afr. J. Microbiol. Res., 7(4): 317-323.

\section{$* * * * * * * *$}

